\title{
Yabancı Dil Olarak Türkçe Öğretim Sürecinde Yazılı Düzeltme Geribildirimleri ve Öğrencilerin Edimsel Çıkarımları
}

\author{
Written Corrective Feedback and Students' Uptake in Teaching Turkish \\ as a Foreign Language
}

\author{
Gökhan ÇETINKAYA* \\ Nihat BAYAT ${ }^{* *}$ \\ Seçil ALACA ${ }^{* * *}$
}

Öz: Bu araştırmanın amacı, yabancı dil olarak Türkçe öğretim sürecinde öğretmenlerin öğrencilerin yazılı metinlerine sundukları düzeltme geribildirimlerini yöneldikleri dilbilgisel boyut ve nitelikleri açısından incelemek, ayrıca geribildirimlerin işlevselliğini ortaya koymaktır. Araştırmanın çalışma grubunda 2 ayrı üniversiteye bağlı TÖMER'de 2014-2015 öğretim yılında B1 düzeyinde öğrenimlerini sürdüren 25 öğrenci ve 6 okutman yer almıştır. Öğrencilere bir metin yazdırılmış, yazdıkları metinler 6 ayrı okutmana paylaştırılarak metinlerde yer alan dilbilgisel yanlışlara yönelik geribildirimler yazmaları istenmiştir. Öğretmenlerin geribildirim verdikleri kağıtlar tekrar öğrencilere dağıtılarak, var olan geribildirimler doğrultusunda aynı metni düzelterek başka bir kağıda yazmaları istenmiştir. Yapılan çözümleme sonucunda, öğrencilerin taslak metinlerinde toplam 608 yanlış saptanmıştır. Öğretmenler ise bu yanlışların 439'una geribildirim vermiştir. Öğretmenler nitelik özelliklerine göre, 357 doğrudan, 82 dolaylı biçimde düzeltme geribildirimi vermiştir. Öğrencilerin tam doğru düzeltme oranı doğrudan geribildirimde yüksekken, dolaylı geribildirimde düşük olmuştur.

Anahtar sözcükler: Yabancılara Türkçe Öğretimi, Yanlış Çözümlemesi, Yazılı Düzeltme Geribildirimi

Abstract: The aim of this research was to investigate teachers' written corrective feedback that they provide to students' on their written texts in terms of head towards linguistic trait and their quality and besides to demonstrate the functionality of the feedback. In the study group for this research, 25 students who were continuing their education at B1 level and six lecturers from two separate universities during the course of the 2014-2015 academic year. The texts written by the students were shared to six individual lecturers and then they were asked to write feedback on the linguistic errors in these draft texts. The papers with the feedback from the teachers were distributed to the students again and they were asked to write the same texts to another paper through correcting according to the feedback givenAs a result of this analysis, a total of 608 errors were determined. The lecturers gave feedback to only 439 of these errors. According to the characteristics of feedback quality, teachers provided 357 direct and 82 indirect feedback. In provided direct feedback, the ratio of students' precise corrections were found higher than for the indirect feedback.

Keywords: Teaching Turkish as a Foreign Language, Error Analysing, Written Corrective Feedback

\footnotetext{
* Doç. Dr., Niğde Üniversitesi, Eğitim Fak., Türkçe Eğitimi Bölümü, Niğde, gokhancetinkaya76@hotmail.com

** Doç. Dr., Akdeniz Üniversitesi, Eğitim Fakültesi Fakültesi, İlköğretim Bölümü, Antalya, nihatbayat@gmail.com

*** Okutman, Niğde Üniversitesi, NÜTÖMER, Niğde, secilalaca@gmail.com

$\mathrm{Bu}$ çalışmanın bir kısmı, 10-12 Haziran 2015 tarihlerinde İspanya Barselona'da gerçekleştirilen International Conference on New Horizons in Education Sempozyumunda sözlü bildiri olarak sunulmuştur.
} 
Yazılı düzeltme geribildirimi, öğretmen ya da akran tarafından öğrencinin oluşturduğu taslak metinde yer alan yanlışlara yönelik doğrudan ve dolaylı yoldan sağlanan bildirimleri kapsar. Son y1llarda öğrencilerin yazma gelişiminde öğretmen geribildiriminin etkisi üzerine çalışmaların yoğunlaştı̆̆1 görülmektedir (Lalande 1982; Shepard 1992; Frantzen 1995; Ferris \& Helt 2000; Ferris 2002; Ferris 2006; Van Beuningen, De Jong \& Kuiken 2008; Ellis 2009; Herrera 2011; Salimi \& Ahmadpour 2015). Alan yazında yer alan çalışmaların bulguları incelendiğinde, anadilinde (bundan sonra D1) ve yabancı dilde (bundan sonra D2) yazma sürecinin benzer yönleri olduğu gibi, D2 yazma sürecinin bazı yönleriyle kendine özgü bir süreci barındırdığ söylenebilir. D2 yazma sürecinde öğrencilerin daha fazla zorlandıkları ve yanlış yaptıklanı görülmektedir. Bu durum öğretmenin sağladığı geribildirimin önemini arttırmaktadır. Geribildirim süreç temelli yazmanın temel bir bileşenidir (Keh 1996, 295). Geribildirimin etkisi, verilen bilginin içerik ve niteliğiyle doğru orantılıdır (Çetinkaya \& Köğce 2014, 115). Çalışmaların sonuçları, süreç içinde verilen etkili geribildirimin öğrencilerin yanlışlarını başarılı bir biçimde düzeltmesini sağladığı ve öğrenme süreçlerini olumlu yönde etkilediği yönündedir (Ferris \& Roberts 2001; Yeh \& Lo 2009; Bitchener \& Knoch 2010). Yazılı düzeltme geribildiriminin etkili olmasında ise geribildirimin yöneldiği boyutun, kullanılan stratejinin ve öğrenci beklentisinin önemli rol oynadığı söylenebilir. Bu yüzden öğretmenin geribildirim verme konusunda yetkin olması beklenir.

Bu çalışmada, yabancı dil olarak Türkçe öğretim sürecinde öğretmenlerin öğrencilerin yazılı metinlerine sundukları geribildirimlerin yöneldikleri dilsel özellikler ile niteliklerinin ve öğrencilerin edimsel çıkarımlarının, yani doğru düzeltme oranlarının incelenmesine odaklanılmıştır.

Çalışmanın dayandığı temel kavramları ve ilgili alan yazın araştırmalarının sonuçlarını ortaya koymak amaciyla, giriş bölümünün alt bölümlerinde D1 ve D2 yazma sürecinin temel özelliklerine ilişkin bilgi verilecek, ardından dilsel yanlışlar ve dil öğretimi sürecinde bu yanlışların düzeltilmesinin önemi üzerinde durulacaktır. Son olarak, alan yazında yapılan ilgili çalışmalara değinilecektir.

\section{Kavramsal Çerçeve}

\section{Anadilinde ve Yabancı Dilde Yazma Süreci}

1990’lı yıllara değin öğretmenlerden D2 öğretimi sürecinde D1 yazma yaklaşımlar1 çerçevesinde uygulama yapmaları önerilirdi. Bu durum, D1 ve D2 yazma sürecinin hemen hemen özdeş ya da en azından benzer olduğu yönünde varsayım gösterir. Ana hatlarıyla D1 ve D2 yazma ediminin benzer yönleri olduğu söylenebilir. Çünkü hem D1 hem D2 yazma sürecinde, yazarlar düşüncelerini yapılandırmak ve bunları ifade edecek uygun retorik ve dilsel yapıları oluşturmak için planlama, yazma ve gözden geçirme işlemlerini içeren yinelemeli bir oluşturma süreci işletirler. Ancak, D1 ve D2 yazma sürecine ilişkin ayrıntılı incelemeler bu iki sürecin belirgin ve önemli farklılıkları olduğuna işaret eder (Silva 1993). Süreçte yer alacak etkinlik ve uygulamaları doğru yapılandırmak açısından, D2 yazma sürecinin kendine özgü yapısını anlamak ve D1 yazma sürecinden ayrılan yönlerini ortaya koymak gerekir.

Daha önceden de belirtildiği gibi, araştırmalar yazılı metni oluşturma aşamaları açısından D1 ve D2'nin benzer olduğunu gösterir. Ancak, çalışmaların sonuçları planlama, yazma ve gözden geçirme aşamalarının alt süreçlerinde belirgin farklılıklar olduğunu ortaya koymaktadır. Örneğin, D2 sürecinde yazarlar, bütünsel ve bölümsel düzlemlere yönelik daha az planlama yaparken daha çok üretme aşamasına odaklanırlar. D2 üretme aşaması D1'e göre daha zordur; bunun yanında akıcılığı ve üretkenliği daha düşüktür. Bölümsel ve bütünsel düzenleme, ayrıca yazının amacını ortaya koyma konusunda da zorluk yaşarlar. D2 yazarları zamanlarını daha çok taslağa ve ne yapmaları gerektiğini belirten yönergeye, ayrıca sözlüğe bakmakla geçirirler. Bunun yanında söz varlığı konusunda zorluk yaşarlar. Bu yüzden D2 yazma süreci sık sık 
kesintiye uğrar. Bu durum, D2 metin oluşturma sürecinin D1'e göre daha yavaş olmasına neden olur.

D2 yazma süreci D1'e göre daha fazla gözden geçirip düzeltme işlemi gerektirir. D2 yazma sürecinde gözden geçirme işlemi daha çok dilbilgisi odaklıdır. Yazım ve noktalama konusunda ise gözden geçirme daha azdır. Yazılı metin özelliklerine bakıldığında D2 metinlerinin daha kısa olduğu görülmektedir. Metinlerin doğruluk oranına bakıldığında, D2 yazarlarının genel olarak daha fazla yanlış yaptığı yönünde bulgular yer almaktadır. Bu yanlışlar içinde biçimselsözdizimsel, sözlüksel-anlamsal, eylem ve ad yanlışları öne çıkmaktadır. D2 metinlerinin nitelik açısından da daha etkisiz olduğu söylenebilir.

D1 ve D2 yazma sürecindeki en büyük fark dilsel yeterliliktir. Düşük yeterlikteki D2 yazarları sözlüksel ve sözdizimsel engellerin üstesinden gelmek zorundadır. Widdowson'a (1983) göre, hedef dilin sözdizimsel kurallarına ilişkin özdevinimsizlik (non-automation) yazarın zihinsel kaynaklarını dilsel zorluğu aşma üzerinde yoğunlaştırdığından söylem işlevi becerisini olumsuz yönde etkiler. D1 yazma becerisi düşük ve yüksek yazarların D2 yazma sürecindeki performansları birbirinden farklıdır. D1 yazma becerisi yüksek yazarlar D2 yazma sürecinde yanlışlarını kendileri düzeltebilirken, beceri düzeyi düşük yazarların düzeltme becerisi daha düşüktür.

D2 yazma sürecinin yukarıda belirtilen kendine özgü özelliklerinden dolay1 öğrencinin taslak metninin gözden geçirilmesi aşamasında öğretmenin öğrencinin yanlışlarına sağlayacağı yazılı düzeltme geribildiriminin odaklandığı boyut ve nitelikler daha da önem taşımaktadır.

\section{Dilbilgisel Yanlışlar ve Dil Öğretimi Sürecinde Bu Yanlışların Düzeltilmesinin Önemi}

Ellis’e (1997, 33 akt. Çetinkaya 2015) göre, öğrencinin dilbilgisi geçicidir. Öğrenciler dilbilgisini kurallar ekleyerek, silerek ve tüm dizgeyi yeniden yapılandırarak sürekli değiştirir. $\mathrm{Bu}$ süreçte, öğrenciler dilbilgisi kurallarını eklediklerinde, sildiklerinde ya da yeniden yapılandırdıklarında yanlışlar oluşur. Türkçede yanlışların dilsel özellikleri açısından "yazımsal", "sesbilimsel”, "sözlüksel-anlamsal”, "sözdizimsel" ve "biç̧imbilimsel” olmak üzere beş ulamda sınıflandırıldığı görülür (Çetinkaya 2015,169).

Long (1996 akt. Wang \& Jiang 2015, 111) tarafindan geliştirilen etkileşim kuramı dil edinim sürecini iç ve dış etmenler arasındaki etkileşim olarak açıklar. İç etmenler dil öğrenme düzeneği olabilirken, diş etmenler hedef dilde neyin kabul edilebilir olduğu hakkındaki olumlu belirtiler ya da hedef dilde neyin kabul edilemez olduğu hakkında olumsuz belirtiler biçiminde girdi olabilir. Dil öğrenim sürecinde yalnızca olumlu belirtilere maruz kalınması yeterli görülmemektedir. Öğrencilerin kabul edilebilir çıktı sağlayabilmesi için düzeltme geribildirimi gibi olumsuz belirtilere de gereksinimi vardır.

\section{Alan Yazına İliş̧kin Görünümler}

Yazılı düzeltme geribildirimi temelde doğrudan ve dolaylı olmak üzere iki ulamda sınıflandırılır. Doğrudan geribildirim öğrencinin yazılı taslak metninde var olan yanlışların öğretmen tarafından açık bir biçimde yazılı olarak düzeltilmesidir. Öte yandan, dolaylı geribildirim ise, öğrencinin yazılı taslak metninde yer alan yanlışın öğretmen tarafından altının çizilmesi, yuvarlak içine alınması, kodla belirtilmesi vb. gibi yazılı eylemleri kapsar (Ferris 1995; Bitchener \& Knoch 2008; Srichanyachon 2012). Edimsel çıkarım (uptake) kavramını ilk kullanan araştırmacılardan biri Chaudron'dur (1977). Chaudron'a (1977) göre, verilen geribildirimin etkisi öğrencinin doğru düzeltme yapabilme durumuna göre değerlendirilir. Daha sonra, Lyster ve Ranta'nın (1997) öğrencilerin edimsel çıkarımlarını “düzeltilmiş” (repair) ve “düzeltme gerekli" (needs repair) biçiminde sınıflandırdığı ve tanımladığı görülür.

Alan yazın incelendiğinde, öğrencilerin yazılı anlatım becerisi ve hedef dili öğrenme geli- 
şimleri açısından doğrudan ve dolaylı geribildirimin etkisine dönük farklı sonuçlar yer aldığ 1 görülür. Bazı çalışmalarda, doğrudan geribildirimin öğrencilerin öğrenmeleri üzerinde daha etkili olduğu yönünde sonuçlar yer alırken (Shepard 1992; Frantzen 1995; Ferris \& Helt 2000; Ferris 2002; Salimi \& Ahmadpour 2015), bazı çalışmaların sonuçları dolaylı geribildirimin daha etkili olduğu yönündedir (Lalande 1982; Van Beuningen, De Jong \& Kuiken 2008; Herrera 2011). Bunun yanında, Frantzen'nin (1995) çalışmasının sonuçları ise, her iki geribildirim türünün arasında bir fark olmadığı yönündedir. Buna ek olarak, öğrenci ve öğretmenlerin doğrudan ve dolaylı geribildirim konusundaki tercihlerini sorgulayan çalışmaların sonuçları, hem öğrencilerin hem de öğretmenlerin doğrudan geribildirimi daha çok tercih ettikleri yönündedir (Ferris \& Roberts 2001; Jodai, Farrokhi \& Zoghi 2011). Ayrıca, doğrudan geribildirimin daha çok başlangıç düzeyi öğrencilerin öğrenmeleri üzerinde ve belli dilbilgisel yapıların öğrenilmesinde yararlı ve etkili olduğu belirtilmektedir (Sheen 2007; Bitcheren 2008).

D2 yazma sürecinde yazılı düzeltme geribildiriminin öğrencilerin yazma edimine katkısı çevresinde alan yazında yer alan çalışmaların sonuçları incelendiğinde olumlu katkısı olduğunu belirten çalışmalar (Ferris \& Roberts 2001; Yeh \& Lo 2009; Bitchener \& Knoch 2010) yanında olumlu bir katkısı olmadığını belirten çalışmalara (Knoblach \& Brannon 1981; Sheppard 1992; Truscott 1999, 2007) da rastlanmaktadır.

Han ve Hyland'ın (2015), öğrencilerin yazılı metinleri, görüşme, geriye dönük sözel bildirimler ve öğretmen-öğrenci konferansları yoluyla veri topladıkları, yabancı dil olarak İngilizce öğrenen Çinli öğrencilerin kavramsal, davranışsal ve duyuşsal olarak yazılı düzeltme geribildirimlerini nasıl işlettiklerini ve algıladıklarını betimlemeye odaklanan çalışmalarının sonuçları öğrencilerin tutumlarının, yazılı düzeltme geribildirimi alma ve D2 yazma deneyimleri ile amaçlarının ve geribildirimin alındığı etkileşimsel bağlamın öğrencilerin süreci işletme ve sürece ilişkin algılarında etkili olduğu yönündedir. $\mathrm{Bu}$ durum bireysel farklılıkların yazılı düzeltme geribildirimine ilişkin algı ve işleme alma konusunda farklılıklar yarattığını gösterir. Bu durumdan hareketle, Han ve Hyland (2015) ilgili çalışmalarında öğretmenlerin yazılı düzeltme geribildirimi verirken öğrencilerin artalanlarını ve tutumlarını göz önünde bulundurarak stratejilerini seçmeleri gerektiğini belirtmektedir.

Kang ve Han'ın (2015) yazılı düzeltme geribildiriminin D2 yazma sürecinde, öğrencilerin dilbilgisel olarak doğru yazma durumlarını geliştirme yönündeki işlevselliğine ilişkin 21 önemli çalışma üzerinde gerçekleştirdiği toplu çözümlemenin sonuçları, yazılı düzeltme geribildiriminin öğrencilerin yazma edimi üzerinde anlamlı gelişme sağladığı yönündedir.

Lee'nin (2008) çalışmasına göre, az sayıda ve öğrenciler tarafından anlaşılabilir olması durumunda düzeltme kodunun kullanılması öğrencilerin edimsel çıkarımlarına olumlu etki edebilmektedir.

Vyatkina'nın (2010) çalışmasına göre, doğrudan geribildirim öğrencilerin düzeltme işlemlerine olumlu katkılar sağlarken, öğrenciler dolaylı ve kodlama biçiminde verilen geribildirimi anlamlandırmakta ve yanlış çıkarımlar yaparak düzeltme yerine başka bir yanlışı yapabilmektedir.

\section{Çalışmanın Önemi ve Amacı}

Yabancı dil olarak Türkçe öğrenim sürecinde B2 düzeyinde öğrenimlerini sürdüren öğrencilerin yazılı anlatımlarında yaptıkları yanlışları betimleyen çalışmaların sonuçları, öğrencilerin yazımsal, sözlüksel-anlamsal, sözdizimsel ve biçimbilimsel yanlışları sıklıkla yaptığını göstermektedir (Bölükbaş 2011; Büyükikiz \& Hasırc1 2013; Şahin 2013; Aytan \& Güney 2015; Ceran \& Çakın 2015; Çetinkaya 2015; Hamzadayı 2015). Öğrencilerin yabanc1 dil öğrenim sürecinde oluşturdukları taslak metinlerde yer alan yanlışların belirlenmesi öğretmenin onların gelişim durumunu görmesi ve öğrencilerin öğrendikleri dildeki dilbilgisel kurallara ilişkin süreç içinde geliştirdikleri yanlış varsayım ve genellemeleri görmesi açısından önemli bir bilgi kaynağıdır. 
Ayrıca, bu yolla öğrenciler de yazılı anlatımlarında yaptıkları yanlışları görebilirler. Fakat öğrencilerin yaptıkları yanlışların temelinde yer alan bilgi eksikliğini giderebilmeleri, öğrenmekte oldukları dilsel yapıya ilişkin oluşturdukları yanlış varsayım ve genellemeleri düzeltip gelişim sağlayabilmeleri için öğretmenin sunduğu yazıll düzeltme geribildirimleri önemli bir işleve sahiptir. Yukarıda konuya ilişskin çalışmaların bulgu ve sonuçları, geribildirimin yöneldiği dilsel özelliklerin ve verilen geribildirim doğrudan ya da dolaylı olmasının öğrencilerin öğrenmeleri üzerinde önemli değişken olduğu yönündedir. Bazı çalışmalarda doğrudan bazı çalışmalarda ise dolaylı geribildirimin öğrencilerin öğrenmeleri üzerinde daha etkili olduğu belirtilmektedir. Türkçe alan yazına bakıldığında, yabancı dil olarak Türkçe öğrenim sürecinde yazılı düzeltme geribildirimleri üzerine bir çalışma bulunmadığı görülmektedir. Öğretmenlerin, öğrencilerin yazılı taslak metinlerine sundukları geribildirimlerin yöneldikleri dilsel özelliklerinin, verilen geribildirimin niteliğinin ve öğrencilerin verilen geribildirimin türüne göre edimsel çıkarımda bulunma durumlarının belirlenmesinin yabancı dil olarak Türkçe öğreten öğretmenlere ve konuyla ilgili çalışma yapan bilim insanlarına önemli katkılar sağlayacağı düşünülmektedir. Ayrıca, araştırmanın çalışma grubundan elde edilen verilerin çözümlenmesiyle elde edilecek bulgular doğrudan ve dolaylı düzeltme geribildiriminin öğrencilerin yanlışlarını düzeltme durumlarına etkisi konusunda önemli bir görünüm sağlayacaktır.

$\mathrm{Bu}$ araştırmanın amacı, yabanc1 dil olarak Türkçe öğretim sürecinde öğretmenlerin öğrencilerin yazılı metinlerine sundukları düzeltme geribildirimlerini, yöneldikleri dilsel özellikler ve nitelikleri açısından incelemektir. Öte yandan, öğretmenler tarafından verilen geribildirimlerin işlevselliğini ortaya koymak için öğrencilerin edimsel çıkarımları, yani doğru düzeltme oranları incelenmiştir. Çalışmanın temel amacı doğrultusunda yanıt aranan alt problemler şunlardır:

1. Öğrencilerin yazılı taslak metinlerinde yer alan yanlışların dilsel özellikleri açısından dağılımları nasıldır?

2. Öğretmenler tarafından sunulan yazılı geribildirimlerin yöneldikleri dilsel özelliklere göre dağılımları nasıldır?

3. Öğretmenlerin öğrencilerin yazılı metinlerine sundukları geribildirimler nitelik özellikleri bakımından nasıl bir dağılım göstermektedir?

4. Öğretmenlerce sunulan yazılı geribildirimler niteliksel özellikleri bakımından ve yöneldikleri boyuta göre nasıl bir görünüm sunmaktadır?

5. Öğrencilerin öğretmenler tarafından sunulan yazılı geribildirimi dikkate alma ve düzeltme durumları yöneldikleri dilsel özellikler açısından nasıl bir görünüm sunmaktadır?

\section{Yöntem}

\section{Araştırmanın Deseni ve Çalışma Grubu}

$\mathrm{Bu}$ araştırma, nitel araştırma yöntemlerinden içerik analizi tekniği kullanılarak gerçekleştirilmiştir. Araştırmanın çalışma grubunda 2 ayrı üniversiteye bağlı TÖMER'de 2014-2015 öğretim yılında B1 düzeyinde öğrenimlerini sürdüren 25 öğrenci ve yabanc1 dil olarak Türkçe öğreten 6 okutman yer almıştır

\section{Verilerin Toplanması ve Çözümlenmesi}

Verilerin toplanması aşamasında öncelikle yabancı dil olarak Türkçe öğrenmekte olan B1 düzeyinde öğrencilerden 200-250 sözcük uzunluğunda bir deneme metni yazmaları istenmiştir. Daha sonra, öğrencilerin ürettikleri yazılı metinler toplanmış ve araştırmacılar tarafindan fotokopi ile iki kopyası oluşturulmuştur. Çoğaltılan metinlerde yer alan dilbilgisi yanlışları iki ayrı araştırmacı tarafından saptanmış ve aşağıda Tablo 1'de yer alan forma yazılarak yanlışın 
türü açısından tanımlanmış ve dağılımları hesaplanmıştır. Öğrencinin yazılı anlatımında yer alan yanlışlar saptandıktan sonra Çetinkaya'nın (2015) sinıflandırması temelinde "yazımsal", "sözlüksel-anlamsal”, “sözdizimsel” ve "biçimbilimsel” özelliklerine göre dört ulamda tanımlanmıştır. Daha sonra, çalışma grubunda yer alan öğretmenlerden öğrencilerin ürettikleri yazılı metinlere geribildirim vermeleri istenmiştir. Bu süreçte öğretmenlere yapması gerekenlerle ilgili açıklamalar yapılmış ve varsa soruları yanıtlanmıştır. Bu doğrultuda, öğretmenlere geribildirimi metin üzerinde işaretlemeler, yorumlar, düzeltmeler vb. işlemler yaparak verebilecekleri belirtilmiştir. Öğretmenlerin verdikleri düzeltme geribildirimlerinin yer aldığı metinler öğrencilere tekrar verilerek öğrencilerden öğretmenlerin verdikleri düzeltme geribildirimleri doğrultusunda metinlerini başka bir kağıda yeniden düzenleyerek yazmaları istenmiş ve yeniden düzenledikleri metinler de tekrar alınmıştır.

İki araştırmacı tarafından öğretmenlerin öğrencilerin ilk taslak metinlerine verdikleri yazılı geribildirimler yöneldikleri dilsel özellikleri ve nitelikleri, öğrencilerin son metinleri geribildirimleri dikkate alma ve doğru düzeltme durumları açısından çözümlenmiş ve dağılımları yüzde ve frekans olarak belirlenmiştir. Çözümleme sürecinde öğretmenlerin öğrenci metinlerine sundukları yazılı geribildirimler, yöneldikleri boyut ve nitelikleri açısından araştırmacının yanı sıra ikisi uzman olmak üzere 3 kişi tarafından tanımlanmıştır. Araştırmacı ile uzmanların çözümlemeleri \%98 oranında örtüşmüştür. Örtüşen çözümlemeler doğrudan alınırken, örtüşmeyen yapılar tartışılarak karara bağlanmıştır.

Verilerin aşağıda Tablo 1'e yazılması ve çözümlenmesi aşamasında ilk olarak öğrencilerin yazılı taslak metinlerinde yer alan yanlışlar, formda yer alan (a) sütununa yazılmış ve dilbilgisel özelliği $(+)$ ile işaretlenerek tanımlanmıştır. Sonra, öğrenci taslak metinlerine öğretmenlerin sağladıkları geribildirimler ilgili tümcenin altında yer alan (b) sütununa yazılmış ve nitelik özelliği (+) ile işaretlenerek tanımlanmıştır. Son olarak, öğrencilerin öğretmenlerin verdikleri yazılı düzeltmeler doğrultusunda yaptıkları düzeltmeler ya da göz ardı ettikleri geribildirimler yine ilgili alan $(+)$ ile işaretlenerek tanımlanmıştır.

Tablo 1. Yanlış Çözümlemesi ve Geribildirim Değerlendirme Formu

\begin{tabular}{|c|c|c|c|c|c|c|c|c|c|c|c|c|c|c|}
\hline \multicolumn{3}{|c|}{ Kat1lımeı no: } & \multicolumn{12}{|c|}{ Metin No: } \\
\hline \multirow{3}{*}{ 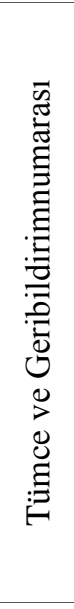 } & \multirow{3}{*}{$\begin{array}{l}\text { (a) } \\
\text { (b) } \\
\text { (c) }\end{array}$} & \multirow{3}{*}{$\begin{array}{l}\text { Yanlış Tümce Geribildirim } \\
\text { Yazılı Düzeltme Geribildirimi } \\
\text { Ögrencinin Düzeltme Eylemi }\end{array}$} & \multicolumn{4}{|c|}{$\begin{array}{l}\text { Dilbilgisel } \\
\text { özellik }\end{array}$} & \multicolumn{4}{|c|}{$\begin{array}{l}\text { Nitelik } \\
\text { Özellikleri }\end{array}$} & \multicolumn{4}{|c|}{ Düzeltme } \\
\hline & & & \multirow[b]{2}{*}{ 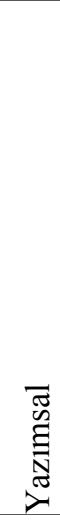 } & \multirow[b]{2}{*}{ 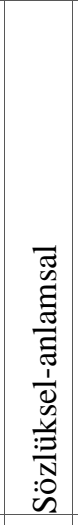 } & \multirow[b]{2}{*}{ 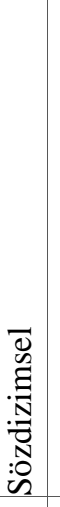 } & \multirow[b]{2}{*}{ 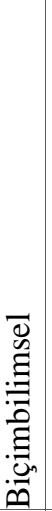 } & \multicolumn{4}{|c|}{$\frac{\sqrt{\mathrm{I}}}{\circ}$} & \multirow[b]{2}{*}{ 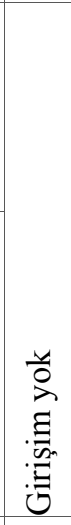 } & \multirow[b]{2}{*}{ 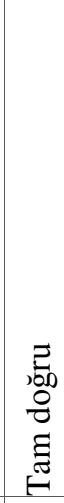 } & \multirow[b]{2}{*}{$\begin{array}{l}\vec{E} \\
0 \\
0 \\
0 \\
\Xi \\
\Xi \\
\bar{\Xi}\end{array}$} & \multirow[b]{2}{*}{ 雲 } \\
\hline & & & & & & & & 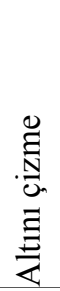 & 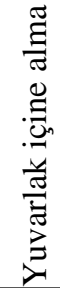 & 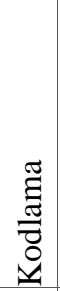 & & & & \\
\hline & $\mathrm{a}$ & & & & & & & & & & & & & \\
\hline & b & & & & & & & & & & & & & \\
\hline & C & & & & & & & & & & & & & \\
\hline & $\mathrm{a}$ & & & & & & & & & & & & & \\
\hline & b & & & & & & & & & & & & & \\
\hline & c & & & & & & & & & & & & & \\
\hline Topl & & & & & & & & & & & & & & \\
\hline
\end{tabular}




\section{Bulgular}

\section{Araştırmanın Birinci Sorusuna İlişkin Bulgular}

Araştırmanın birinci sorusu "Öğrencilerin yazılı taslak metinlerinde yer alan yanlışların dilsel özellikleri açısından dağılımları nasıldır?" biçiminde oluşturulmuştur. Elde edilen bulgular aşağıda Tablo 2'de gösterilmektedir:

Tablo 2. Dilsel Özellikleri Bakımından Yanlışların Dağılımı

\begin{tabular}{lcc} 
Yanlış Ulamı & $\mathrm{f}$ & $\%$ \\
\hline Yazımsal & 284 & 46,71 \\
\hline Sözlüksel-anlamsal & 71 & 11,68 \\
\hline Sözdizimsel & 62 & 10,20 \\
\hline Biçimbilimsel & 191 & 31,41 \\
\hline Toplam Yanlış Sayısı & 608 & 100
\end{tabular}

Öğrencilerin yazılı taslak metinlerinde yer alan yanlışların dilsel özellikleri açısından dağılımlarını gösteren Tablo 2 incelendiğinde, yazımsal yanlışların \%46,71 oranla en fazla sıklığa sahip olduğu görülmektedir. Bu yanlış türünü \%31,41 oranla biçimbilimsel yanlışlar izlemektedir. $\% 11,68$ oranla sözlüksel-anlamsal ve $\% 10,20$ oranla sözdizimsel yanlışlar ise bütünce içinde daha düşük bir sıklığa sahiptir.

\section{Araştırmanın İkinci Sorusuna İliş̧kin Bulgular}

Araştırmanın ikinci sorusu “ ̈Ögretmenler tarafindan sunulan yazılı geribildirimler yöneldikleri dilsel özellikler ve niteliklerine göre dağılımları nasıldır?" biçiminde oluşturulmuştur. Elde edilen bulgular aşağıda Tablo 3'te gösterilmektedir:

Tablo 3. Öğretmenlerin Sundukları Yazılı Geribildirimlerin Yönelimlerine İlişkin Dağılım

\begin{tabular}{lll} 
Geribildirimin Yöneldiği Boyut & $\mathrm{f}$ & $\%$ \\
\hline Yazımsal & 204 & 46,47 \\
\hline Sözlüksel-anlamsal & 44 & 10,02 \\
\hline Sözdizimsel & 35 & 7,97 \\
\hline Biçimbilimsel & 156 & 35,54 \\
\hline Toplam & 439 & 100
\end{tabular}

Tablo 3'e göre, öğretmenler $\% 46,47$ oranla yazımsal, \%35,54 oranla biçimbilimsel, $\% 10,02$ oranla sözlüksel-anlamsal ve \%7,97 oranla sözdizimsel yanlışlara geribildirim sağlamıştır.

\section{Araştırmanın Üçüncü Sorusuna İlişkin Bulgular}

Araştırmanın üçüncü sorusu "Öğretmenlerin öğrencilerin yazılı metinlerine sundukları geribildirimler nitelik özelliklerine göre nasıl bir dă̆llım göstermektedir?” biçiminde oluşturulmuştur. Elde edilen bulgular aşağıda Tablo 4'te gösterilmektedir: 
Tablo 4. Yazılı Geribildirimlerin Nitelik Özelliklerine Göre Dağılımları

\begin{tabular}{llllll}
\hline Geribildirimler & $\mathrm{f}$ & $\%$ & & \\
\hline Doğrudan & 357 & 81,32 & & $\mathbf{f}$ & $\mathbf{\%}$ \\
\hline \multirow{2}{*}{ Dolaylı } & \multirow{2}{*}{82} & \multirow{2}{*}{18,68} & Altını çizme & 61 & 74,39 \\
& & & Yuvarlak içine alma & 12 & 14,63 \\
& & & Kodlama & 9 & 10,98 \\
\hline Toplam & 439 & & & 82 & 100 \\
\hline
\end{tabular}

Tablo 4'e göre, katılımc1 öğretmenlerin $\% 81,32$ oranla doğrudan ve $\% 18,68$ oranla dolaylı geribildirim vermişlerdir. Dolaylı geribildirim türünün alt ulamları açısından dağılımlara bakıldığında, $\% 74,39$ oranla altını çizme, $\% 14,63$ oranla yuvarlak içine alma ve $\% 10,98$ oranla kodlama türünde geribildirim verdikleri görülmektedir.

\section{Araştırmanın Dördüncü Sorusuna İlişskin Bulgular}

Araştırmanın dördüncü sorusu "Öğretmenlerce sunulan yazılı geribildirimler nitelik özellikleri ve yöneldikleri boyuta göre nasıl bir görünüm sunmaktadır" biçiminde oluşturulmuştur. Elde edilen bulgular aşağıda Tablo 5’te gösterilmektedir:

Tablo 5. Geribildirimlerin Nitelik Özelliklerinin Yöneldikleri Boyutlara Göre Dağılımı

\begin{tabular}{|c|c|c|c|c|c|c|c|c|c|c|}
\hline \multirow{4}{*}{ Boyut } & \multicolumn{10}{|c|}{ Nitelik Özellikleri } \\
\hline & \multicolumn{2}{|c|}{ Doğrudan } & \multicolumn{8}{|c|}{ Dolaylı } \\
\hline & \multirow[b]{2}{*}{$\mathbf{f}$} & \multirow[b]{2}{*}{$\%$} & \multicolumn{2}{|c|}{ Altını Çizme } & \multicolumn{2}{|c|}{$\begin{array}{l}\text { Yuvarlak } \\
\text { İçine Alma }\end{array}$} & \multicolumn{2}{|c|}{ Kodlama } & \multicolumn{2}{|c|}{ Toplam } \\
\hline & & & $\mathbf{f}$ & $\%$ & f & $\%$ & f & $\%$ & $\mathbf{f}$ & $\%$ \\
\hline Yazımsal & 169 & 82,84 & 25 & 12,25 & 6 & 2,94 & 4 & 1,96 & 204 & 100 \\
\hline Sözlüksel-anlamsal & 34 & 77,27 & 10 & 22,73 & 0 & 0,00 & 0 & 0,00 & 44 & 100 \\
\hline Sözdizimsel & 16 & 45,71 & 10 & 28,57 & 6 & 17,14 & 3 & 8,57 & 35 & 100 \\
\hline Biçimbilimsel & 138 & 88,46 & 16 & 10,26 & 0 & 0,00 & 2 & 1,28 & 156 & 100 \\
\hline
\end{tabular}

Tablo 5 incelendiğinde, öğretmenlerin yazımsal yanlışlara verdiği toplam geribildirimden 169'unun doğrudan, 35'inin dolaylı olduğu görülmektedir. Dolaylı geribildirimin alt ulamlarına göre öğretmenlerin yazımsal yanlışlara verdikleri geribildirimlerin 25 ' $\mathrm{i}$ altını çizme, 6 'sı yuvarlak içine alma ve 4'ü kodlama biçimindedir. Öğretmenlerin tabloda ikinci sırada yer alan sözlüksel-anlamsal yanlışlara verdiği toplam 44 geribildirimden 34'ü doğrudan, 10'u dolaylı biçimde olmuştur. Dolaylı geribildirimin alt ulamında öğretmenlerin sözlüksel-anlamsal yanlışlara verdikleri geribildirimlerin tamamı altını çizme biçimindedir. Tabloda üçüncü sırada yer alan sözdizimsel yanlışlara ilişkin toplam 35 geribildirimin 16'sı doğrudan, 19'u ise dolaylıdır. Dolaylı geribildirimlerin 10'u altını çizme, 6'sı yuvarlak içine alma ve 3'ü de kodlama biçimindedir. Son olarak, biçimbilimsel yanlışlara ilişkin verilen geribildirimlerin nitelik özelliklerine bakıldığında, 138'inin doğrudan, 18'inin de dolaylı olduğu görülmektedir. Dolaylı geribildirimlerin 16'sı altını çizme, 2'si de kodlama biçimindedir.

\section{Araştırmanın Beşinci Sorusuna İlişkin Bulgular}

Araştırmanın beşinci sorusu "Öğrencilerin öğretmenler tarafindan sunulan yazılı geribildirimi dikkate alma ve düzeltme durumları yöneldikleri dilsel özellikler açısından nasıl bir görünüm sunmaktadır?" biçiminde oluşturulmuştur. Elde edilen bulgular aşağıda Tablo 6'da gösterilmektedir: 
Tablo 6. Öğrencilerin Yazılı Geribildirimleri Yöneldikleri Dilsel Özelliklerine Göre Dikkate Alma ve Düzeltme Durumları

\begin{tabular}{lllllllllll}
\hline \multirow{2}{*}{ Dilsel özellik } & \multicolumn{2}{c}{ Girişim Yok } & \multicolumn{2}{c}{ Tam Doğru } & \multicolumn{2}{c}{$\begin{array}{c}\text { Yarım } \\
\text { Doğru }\end{array}$} & \multicolumn{2}{c}{ Yanlış } & \multicolumn{2}{c}{ Toplam } \\
\cline { 2 - 12 } & $\mathbf{f}$ & $\mathbf{\%}$ & $\mathbf{f}$ & $\mathbf{\%}$ & $\mathbf{f}$ & $\mathbf{\%}$ & $\mathbf{f}$ & $\mathbf{\%}$ & $\mathbf{f}$ & $\mathbf{\%}$ \\
\hline Yazımsal & 43 & 21,08 & 109 & 53,43 & 29 & 14,22 & 23 & 11,27 & 204 & 100 \\
\hline Sözlüksel-anlamsal & 9 & 20,45 & 24 & 54,55 & 8 & 18,18 & 3 & 6,82 & 44 & 100 \\
\hline Sözdizimsel & 7 & 20,00 & 21 & 60,0 & 2 & 5,71 & 5 & 14,29 & 35 & 100 \\
\hline Biçimbilimsel & 26 & 16,67 & 81 & 51,92 & 21 & 13,46 & 28 & 17,95 & 156 & 100 \\
\hline
\end{tabular}

Dilsel özellikler açısından öğrencilerin yazılı geribildirimi dikkate alma ve düzeltme durumlarını içeren Tablo 6 incelendiğinde, öğrencilerin yazımsal yanlışların \%21,8'ini düzeltme girişiminde bulunmadıkları, \%53,43’ünü tam , \%14,22'sini yarım biçimde doğru düzelttikleri, $\% 11,27$ 'sini ise düzeltmeye çalıştıkları fakat yapılan düzeltmenin yanlış olduğu görülmektedir. Öğrencilerin sözlüksel-anlamsal yanlışlara ilişkin düzeltme geribildirimlerini dikkate alma ve düzeltme durumlarına bakıldığında $\% 20,45$ oranında girişim olmadığı, $\% 54,55$ oranında tam, $\% 18,18$ oranında yarım doğru düzeltme yapabildikleri ve düzeltmelerin $\% 6.83$ 'ünü yanlış yaptıkları görülmektedir. Öğrenciler sözdizimsel yanlışlara verilen yazılı düzeltme geribildirimlerinin \%20,00'sine girişimde bulunmamış, \%60,00'ını tam, \%5,71'ini yarım doğru düzeltmişler, \%14,29'unu ise yanlış düzeltmişlerdir. Son olarak öğrenciler biçimbilimsel yanlışlara verilen yazılı düzeltme geribildirimlerinin \%16,67'sine girişimde bulunmamış, \%51,92'sini tam, $\% 13,46$ 'sını yarım doğru düzeltmişler ve $\% 17,95$ 'inde yanlış düzeltme yapmışlardır.

\section{Araştırmanın Altıncı Sorusuna İlişkin Bulgular}

Araştırmanın altıncı sorusu "Öğrencilerin ögretmenler tarafindan sunulan yazılı geribildirimi dikkate alma ve düzeltme durumları geribildirimlerin nitelikleri açısından nasıl bir görünüm sunmaktadır?" biçiminde oluşturulmuştur. Elde edilen bulgular aşağıda Tablo 7'de gösterilmektedir:

Tablo 7. Öğrencilerin Yazılı Geribildirimi Nitelikleri Açısından Dikkate Alma ve Düzeltme Durumlar1

\begin{tabular}{llcccccccccc}
\hline \multirow{2}{*}{ Dilsel Özellik } & \multicolumn{2}{c}{ Girişim Yok } & \multicolumn{2}{c}{ Tam Doğru } & \multicolumn{2}{c}{ Yarım Doğru } & \multicolumn{2}{c}{ Yanlış } & \multicolumn{2}{c}{ Toplam } \\
\cline { 2 - 12 } & $\mathbf{f}$ & $\mathbf{\%}$ & $\mathbf{f}$ & $\mathbf{\%}$ & $\mathbf{f}$ & $\mathbf{\%}$ & $\mathbf{f}$ & $\mathbf{\%}$ & $\mathbf{f}$ & $\mathbf{\%}$ \\
\hline \multirow{2}{*}{ Doğrudan } & 51 & 14,29 & 211 & 59,10 & 50 & 14,01 & 45 & 12,60 & 357 & 100 \\
\hline \multirow{2}{*}{ Dolaylı } & $\begin{array}{l}\text { Altını } \\
\text { Çizme }\end{array}$ & 23 & 37,70 & 19 & 31,15 & 8 & 13,11 & 11 & 18,03 & 61 & 100 \\
\cline { 2 - 12 } & $\begin{array}{l}\text { Yuvarlak } \\
\text { içine alma }\end{array}$ & 7 & 58,33 & 3 & 25,0 & 1 & 8,33 & 1 & 8,33 & 12 & 100 \\
\cline { 2 - 12 } & Kodlama & 4 & 44,44 & 2 & 22,22 & 1 & 11,11 & 2 & 22,22 & 9 & 100 \\
\cline { 2 - 12 } & Toplam & 34 & 41,46 & 24 & 24,27 & 10 & 12,20 & 14 & 17,07 & 82 & 100 \\
\hline Genel Geribildirim & 85 & 19,36 & 235 & 53,53 & 60 & 13,67 & 59 & 13,44 & 439 & 100 \\
\hline
\end{tabular}

Nitelik özellikleri açısından öğrencilerin geribildirimleri dikkate alma ve düzeltme durumlarını içeren Tablo 7 incelendiğinde, doğrudan geribildirimlerin \%14,29'una düzeltme girişiminde bulunulmadığ yanlış düzeltildiği görülmektedir.

Dolaylı geribildirim türünün altında yer alan altını çizme geribildirimine ilişkin öğrencilerin dikkate alma durumlarına bakıldığında \%37,70'ine girişimde bulunmadıkları, \%25'ini tam, $\% 13,11$ 'ini yarım olarak doğru düzelttikleri ve \%18,03'ünü yanlış düzelttikleri görülmektedir. 
Yuvarlak içine alma geribildirimine ilişkin veriler incelendiğinde öğrencilerin verilen geribildirimlerin $\% 58,33$ 'üne girişimde bulunmadıkları, \%50'ini tam, \%8,33'ünü yarım doğru düzelttikleri ve $\% 8,33$ 'ünü yanlış düzelttikleri anlaşılmaktadır. Kodlama geribildirimine ilişkin dağılıma göre, öğrencilerin verilen düzeltme geribildirimlerinin \%44,44'üne girişimde bulunmamış, \%22,22'sini tam, \%11,11'ini yarım olarak doğru düzeltmişler, \%22,22'sini ise yanlış düzeltmişlerdir.

Dolaylı geribildirimlerin öğrenciler tarafından dikkate alınma ve düzeltilme durumlarının genel görünümüne bakıldığında, \%41,46'sına girişimde bulunulmadığı, \%24,27'sinin tam, \%12,20'sinin yarım olarak doğru düzeltildiği ve \%17,07'sinin yanlış düzeltildiği anlaşılmaktadır.

Nitel özellikler açısından geribildirimlerin dikkate alınma ve düzeltilme durumları bütün olarak değerlendirildiğinde, öğrencilerin verilen geribildirimlerin \%19-39'una düzeltme girişiminde bulunmadığı, \%53,53'ünü tam, \%13,67'sini yarım doğru düzelttiği ve \%13,44'ünü yanlış düzelttiği görülmektedir.

\section{Sonuç ve Tartışma}

Yabancı dil olarak Türkçe öğretim sürecinde öğretmenlerin öğrencilerin taslak metinlerine sundukları yazılı düzeltme geribildirimleri yöneldikleri dilsel özellikler ile nitelikleri açısından incelenmiş, ayrıca verilen bu geribildirimlerin işlevselliğini ortaya koymak amacıyla öğrencilerin dikkate alma ve doğru düzeltme durumları yani edimsel çıkarımları betimlenmiştir.

Öğretmenlerin hangi yanlışlara ne sıklıkla düzeltme geribildirimi verdiğine ilişkin görünümü anlamak amacıyla öğrencilerden elde edilen taslak metinlerde yer alan yanlışlar öncelikle araştırmacılar tarafından saptanmış ve türüne göre tanımlanmıştır. Yapılan çözümlemeye göre, B1 düzeyindeki 25 katılımcı öğrencinin taslak metinlerinde toplam 608 yanlış saptanmıştır. Bu yanlışların 284'ü yazımsal, 71'i sözlüksel-anlamsal, 62'si sözdizimsel ve 191'i biçimbilimsel türde tanımlanmıştır. Öte taraftan, öğretmenlerin öğrencilerin taslak metinlerine sundukları geribildirim sayıs1 439'dur. Yani, öğretmenler öğrencilerin taslak metinlerinde yer alan toplam 169 yanlışa düzeltme geribildirimi sunmamıştır. Yanlış ulamları açısından bakıldığında, öğretmenlerin yazımsal yanlışların 80'ine $(\% 28,17)$, sözlüksel-anlamsal yanlışların 27'sine $(\% 38,03)$, sözdizimsel yanlışların 27 'sine $(\% 43,55)$ ve biçimbilimsel yanlışların 35 'ine $(\% 18,32)$ düzeltme geribildirimi sağlamadığı görülmüştür. Çıkan sonuca göre, öğretmenlerin en fazla oranla göz ard1 ettikleri alan sözdizimsel yanlışlar olmuştur. Oysa alan yazına bakıldığında D2 yazma sürecinde öğrencilere en karmaşık gelen dilsel yapının sözdizimi olduğu görülür (Hosseing 2014).

Öğretmenler nitelik özelliklerine göre, 357 doğrudan $(\% 81,32), 82$ dolaylı $(\% 18,60)$ biçimde düzeltme geribildirimi vermiştir. Burada dikkat çeken diğer bir sonuç, dolaylı geribildirim içinde yer alan kodlama türünde geribildirimin çok az kullanılmış olmasıdır. Bu durumun nedeni katılımcı öğretmenlerin kısaltmaları nasıl kullanacă̆ını bilmemesi olabilir.

Sağlanan düzeltme geribildirimlerinin yöneldikleri yanlış türlerine göre nitelik özelliklerine bakıldığında doğrudan geribildirimin yazımsal, sözlüksel-anlamsal ve biçimbilimsel boyutlarda \%77,27-\%88,64 aralığında büyük bir oranla kullanıldığı görülmüştür. Dolaylı geribildirimin ise yalnızca sözdizimsel yanlışlara geribildirim verilirken \%54,29 oranla tercih edilmiş olması dikkat çekicidir. Öğretmenlerin sözdizimsel yapıda yer alan yanlışa açıklama yaparak ya da yanlışı tümüyle düzelterek geribildirim vermesi daha çok zaman almaktadır. Bu yüzden, öğretmenlerin yanlış yerde bulunan öğenin olması gereken yeri okla göstermesi daha kolay görünmektedir. Fakat böyle bir geribildirim karşında öğrenci bilişsel olarak herhangi bir çaba ve gelişim sağlamaz. Bu yüzden de, öğrencinin yeni metin oluşturma sürecinde aynı yanlışı yapması olasidir.

Öğretmenlerin verdikleri düzeltme geribildirimlerine karş1lı öğrenciler tüm boyutlarda yanlışların 85'ine düzeltme girişiminde bulunmamıştır. Boyutlar açısından öğrencilerin tam 
doğru düzeltme oranının sözdizimsel yanlışlarda en yüksek orana sahip olduğu görülmüştür. Dolaylı geribildirimin de en yüksek oranda bu yanlış türünde kullanıldığı düşünüldüğünde bu sonuç dikkat çekicidir. Yukarıda da belirtildiği gibi, öğretmenin öğenin bulunması gereken doğru yeri işaret etmesi ve öğrencinin mekanik bir biçimde düzeltmeyi gerçekleştirmesi bu başarının kaynağının olası nedenidir.

En düşük yanlış düzeltme girişimine sözlüksel-anlamsal, en yüksek yanlış düzeltme girişimine ise biçimbilimsel yanlış türlerinde rastlanmıştır. Sözlüksel-anlamsal yanlışların temelinde öğrencinin bağlama uygun sözcük konusundaki bilgi eksikliği yatar. Bağlama uygun sözcük ya öğrencinin sözlükçesinde yoktur ya da sözcük değeri konusundaki bilgisi yetersizdir. Bu yüzden öğretmenin özellikle sözlüksel-anlamsal yanlışlara açık ve ayrıntılı geribildirim sağlaması öğrencinin düzeltme ve sözcük edinimi açısından önemlidir. Öte yandan, öğrencinin metninde yer alan "masala" gibi bir sözcüğün yazım yanlışına karşılık öğretmenin "mesela biçimimde yazılması gerekir" gibi doğrudan sağladığı geribildiriminin öğrenciler tarafindan dikkate alındığ 1 ve metinde geçen aynı sözcüklerin yazımını da düzelttikleri görülmüştür.

Öğrencilerin en az dikkate aldıkları, yani düzeltme girişiminde bulunmadıkları geribildirim türü dolaylı geribildirim olmuştur. Öğrenciler neredeyse bu geribildirim türünün yarısında düzeltme girişiminde bulunmamıştır. Doğrudan geribildirimde ise bu oran çok düşüktür. Pienemann'ın (1989) “işlenebilirlik kuramı”na (processability theory) göre dil üretimi sırasında etkinleşen bir dizi işlemleme basamağı vardır ve öğrenciler yalnızca gelişimsel olarak hazır oldukları belli bir yapıyı ya da yapıları edinebilirler. Hedeflenen dilsel yapı öğrencinin gelişim düzeyinin üstünde olduğunda yazılı düzeltme geribildirimi etkili olmaz. Chandler’a (2003) göre, dolaylı geribildirim yetersiz bilgiye sahip öğrencilere sunulduğunda, bu öğrencilerin özellikle sözdizimsel yanlışlar gibi karmaşık yapıları düzeltmesi mümkün olamamaktadır. Bu çalışmada da öğrencilerin dolaylı geribildirimi en az dikkate almış olmalarının öğrencilerin bilgi eksikliğinden kaynaklanıyor olabileceği söylenebilir. Bunun yanında, bir diğer nedeni de öğretmenlerin verdikleri geribildirimlerin öğrenciler tarafından tam olarak anlaşılamaması olabilir. Srichanyochon (2012) öğretmen öğrencinin vermek istediği anlamı yanlış yorumlad1ğında verdiği doğrudan geribildirim öğrencinin kafasını karıştırabildiğini ve bu durumun ögrencinin verilen geribildirimi dikkate almamasına ya da yanlış düzeltme yapmasına neden olabildiğini belirtmektedir. Araştırmacıya göre, öğrenci verilen geribildirimden farklı bir düşünceye sahip olduğunda, öğretmenin geribildiriminin geçersiz ya da yanlış olduğunu düşünerek düzeltmeyi reddedebilmektedir. Öğretmenler öğrencinin hedef dildeki art alanını göz önünde bulundurmalı ve onlardan düzeylerine uygun düzeltmeler beklemelidir. Hedef dildeki bilgilerini artırabilmeleri ve başarılı düzeltmeler yapabilmeleri için anlaşılır açıklamalar yapmalıdır.

Ayrıca, öğrencilerin tam doğru düzeltme oranı yine doğrudan geribildirimde yüksekken, dolaylı geribildirimde düşük olmuştur. Yanlış düzeltme oranı da dolaylı geribildirimde daha yüksektir. Konuyla ilgili çalışmaların bulgularına göre, doğrudan geribildirim, öğrencilerin verilen geribildirimi anlaması bakımından daha açıktır; sözdizimsel yapı gibi karmaşı yanlış türleriyle nasıl başa çıkacakları konusunda öğrencilere daha çok açık bilgi sağlar; hedef dilin kullanımı konusunda geliştirdikleri varsayımları sınamaları için doğrudan bilgi sunar (Wang \& Jiang 2015). Hendrikson (1984) öğretmenin düzeltme stratejisini seçerken "öğrencinin hedef dildeki yeterlilik durumunu”, "hedef dili ögrenme amaçlarını", “yanlışın türünü” ve “öğrencinin yanlışı düzeltmeye yönelik tutumunu” göz önünde bulundurması gerektiğini belirtmektedir. Doğrudan geribildirim öğrenciye yanlışını nasıl düzelteceği konusunda açık bilgi sağlamaktadır. Öğretmen bazen yanlış yapıyı kendisi düzeltip, doğrusunu hazır bir biçimde öğrenciye verir. Dolaylı geribildirimde öğrencinin yanlışı görmesi ya da sezmesi sağlanır. Yanlışı öğrencinin kendisinin düzeltmesi beklenir. Dolaylı geribildirim içinde yer alan kodlama stratejisi ise bazen öğrenciler için daha da karmaşık olabilmektedir. Dolaylı geribildirime karşılık öğrencilerin 
doğru düzeltme ya da düzeltme girişiminin düşük olması öğretmenlerin kullandığı sembolleri anlamamasından kaynaklanıyor olabilir. Kavcar, Oğuzkan ve Sever (1995) yazıyı düzeltenle, yazısı düzeltilen arasında işaretlerle bir iletişim kurulabilmesi için öncelikle bu kısaltmaların anlamlarının öğretmen tarafından öğrencilere yazdırılması ve öğretilmesi gerektiğini belirtmektedirler. "C.krk" kısaltması "cümlenin, sözdizimi yönünden yeniden düzenlenmesi gerekir" anlamına gelmektedir. "Ye.d" kısaltması ise "yerinde olmayan söz, deyim, düşünce, benzetme, anlatım" anlamında kullanılır. Öğrencilerin yanlışını anlayabilmesi için bu kısaltmaları bilmesi gerekir. D1 yazma sürecinde de öğrencilerin anlamadığı ve karmaşı bulduğu geribildirimleri düzeltme konusunda sıkıntı yaşadıkları görülmektedir (bk. Ülper 2012).

Sonuç olarak, katılımcı öğrencilerin sunulan yazılı düzeltme geribildirimlerine karşı edimsel çıkarımları istendik düzeyde olmamıştır. Bu durumun temel nedeni olarak öğretmenlerin sundukları geribildirimlerin niteliği görülebilir. Çünkü öğrencilerin başarılı bir edimsel çıkarım gerçekleştirebilmesi için verilen geribildirimin yöneldiği yanlış türüne, öğrencinin gelişim düzeyine, konunun odağına uygun olması gerekir. 


\section{KAYNAKÇA}

Aytan T. \& Güney N. (2015). "TürkçeyiYabancı Dil Olarak Öğrenen Öğrencilerin Yazılı Anlatımlarında Karşılaşılan Sorunlar (Yıldız Tömer Örneklemi)”. International Journal of Languages’ Education and Teaching 3/2 (2015) 275-288.

Bitchener J. \& Knoch U. (2008). "The Value of Written Corrective Feedback for Migrant and International Students". Language Teaching Research Journal 12 (2008) 409-431.

Bitchener J. (2008). "Evidence in Support of Written Corrective Feedback”. Journal of Second Language Writing 17/2 (2008) 102-118.

Bitchener J. \& Knoch U. (2010). "The Contribution of Written Corrective Feedback to Language Development: A Ten Month Investigation”. Applied Linguistics 31 (2010) 193-214.

Bölükbaş F. (2011). “Arap Öğrencilerin Türkçe Yazılı Anlatım Becerilerinin Değerlendirilmesi”. Turkish Studies 6/3 (2011) 1357-1367.

Büyükikiz K. K. \& Hasırcı S. (2013). "Yabancı Dil Olarak Türkçe Öğrenen Öğrencilerin Yazılı Anlatımlarının Yanlış Çözümleme Yaklaşımına Göre Değerlendirilmesi”. Ana Dili Eğitimi Dergisi $1 / 4$ (2013) 51-62.

Ceran D., Yıldız D. \& Çakın E. (2015). "Yabancı Dil Olarak Türkçenin Öğreniminde Yazılı ve Sözlü Anlatımlarda Yapılan Yanlışlar: Japon Örneği”. International Journal of Languages’ Education and Teaching UDES (2015) 476-494.

Chandler J. (2003). "The Efficacy of Various Kinds of Error Feedback for Improvement in the Accuracy and Fluency of L2 Student Writing”. Journal of Second Language Writing 12 (2003) 267-296.

Chaudron C. (1977). "A Descriptive Model of Discourse in the Corrective Treatment of Learners' Errors”. Language Learning 27 (1977) 29-46.

Çetinkaya G. (2015). "Yanlış Çözümlemesi: Yabancı Dil Olarak Türkçe Öğrenen B2 Düzeyindeki Öğrencilerin Yazılı Metinlerine Ilişkin Görünümler”. International Journal of Languages’ Education and Teaching 3/1 (2015) 164-178.

Çetinkaya G. \& Köğce D. (2014). "Ortaokul Türkçe ve Matematik Öğretmenlerinin Öğrencilere Verdikleri Sözel Geribildirimlerin İncelenmesi”. Türkiye Sosyal Araştırmalar Dergisi 18/2 (2014) 113-136.

Ellis R. (2009). “Corrective Feedback and Teacher Development”. L2 Journal 1/1 (2009) 3-18.

Ferris D. R. (2002). Treatment of Error in Second Language Student Writing. Ann Arbor 2002.

Ferris D. R. (2006). "Does Error Feedback Help Student Writers? New Evidence on the Short and LongTerm Effects of Written Error Correction”. Eds. K. Hyland \& F. Hyland. Feedback in Second Language Writing: Contexts and Issues (2006) 81-104. Cambridge.

Ferris D. R. \& Roberts B. (2001). "Error Feedback in L2 Writing Classes: How Explicit Does it Need to Be?”. Journal of Second Language Writing 1 (2001) 161-184.

Ferris D. R. \& Helt M. (2000). Was Truscott Right? New Evidence on the Effects of Error Correction in L2 Writing Classes. Vancouver 2000.

Ferris D. R. (1995). “Teaching ESL Composition Students to Become Independent Self- Editors”. TESOL Journal 4 (1995) 18-22.

Frantzen D. (1995). "The Effects of Grammar Supplementation on Written Accuracy in an Intermediate Spanish Content Course”. Modern Language Journal 79 (1995) 244-329.

Hamzadayı E. (2015). "Yabancılara Türkçe Öğretiminde C1 Düzeyinde Yazılı Akran Geribildirimlerine Ilişkin Görünümler”. Journal of World of Turks 7/2 (2015) 287-298.

Han Y. \& Hyland F. (2015). "Exploring Learner Engagement with Written Corrective Feedback in a Chinese Tertiary EFL Classroom”. Journal of Second Language Writing 30 (2015) 31-44.

Hendrickson J. M. (1984). “The Treatment of Error in Writing Work”. Ed. S. Mckay. Composing in a Second Language (1984) 145-159. Rowley.

Herrera S. (2011). Exploring the Role of Corrective Feedback in Second Language Writing. Unpublished MA Dissertation. University of British Columbia, Vancouver 2011. 
Hosseing M. (2014). "The Role of Direct and Indirect Written Corrective Feedback in Improving Iranian EFL Students’ Writing Skill”. Procedia-Social and Behavioral Sciences 98 (2014) 668-674.

Jodaie M., Farrokhi F. \& Zoghi M. (2011). "A Comparative study of EFL Teachers' and Intermediate High School Perceptions of Written Corrective Feedback on Grammatical Errors”. English Language Teaching 4/4 (2011) 36-48.

Kang E. \& Han Z. (2015). "The Efficacy of Written Corrective Feedback in Improving L2 Written Accuracy: A Meta-Analysis”. The Modern Language Journal 99 (2015) 1-18.

Kavcar C., Oğuzkan F. \& Sever S. (1995). Türkçe Öğretimi. Ankara 1995.

Keh C. L. (1996). "Feedback in the Writing Process: A Model and Methods for Implementation”. Eds. T. Hedge \& N. Power Whitney. Practice and Pedagogy (1996) 271-282. Oxford.

Knoblauch C. H. \& Brannon L. (1981). "Teacher Commentary on Student Draft: The State of the Art”. Freshman English News 10 (1996) 1-4.

Lee I. (2008). 'Understanding Teachers' Written Feedback Practices in Hong Kong Secondary Classrooms”. Journal of Second Language Writing 17 (2008) 69-85.

Lyster R. \& Ranta L. (1997). "Corrective Feedback and Learner Uptake: Negotiation of Form in Communicative Classrooms”. Studies in Second Language Acquisition 19 (1997) 37-66.

Pienemann M. (1989). "Is Language Teachable? Psycholinguistic Experiments and Hypotheses”. Applied linguistics 10 (1989) 52-79.

Şahin E. Y. (2013). "Yabancı Dil Olarak Türkçe Öğrenen Öğrencilerin Yazılı Anlatımlarındaki Ek Yanlışları”. Tarih Okulu Dergisi 6/XV (2013) 433-449.

Salimi A. \& Ahmadpour M. (2015). "The Effect of Direct vs. Indirect Written Corrective Feedback on L2 Learners Written Accuracy in EFL Context”. International Journal of English Language and Literature Studies 4/1 (2015) 10-19.

Sheen Y. (2007). "The Effect of Focused Written Corrective Feedback and Language Aptitude on ESL Learners’ Acquisition of Articles”. TESOL Quarterly 41 (2007) 255-283.

Sheppard K. (1992). “Two Feedback Types: Do They Make a Difference?”. RELC journal 23/1 (1992) 103-110.

Silva T. (1993). "Toward an Understanding of the Distinct Nature of L2 Writing: The ESL Research and its Implications”. TESOL Quarterly 27/4 (1993) 657-677.

Srichanyachon N. (2012). “Teacher Written Feedback for L2 Learners' Writing Development”. Silpakorn University Journal of Social Sciences, Humanities, and Arts 12/1 (2012) 7-17.

Truscott J. (1999). "The Case for 'the Case against Grammar Correction in L2 Writing Classes': A Response to Ferris”. Journal of Second Language Writing 8/2 (1999) 111-122.

Truscott J. (2007). "The Effect of Error Correction on Learners' Ability to Write accurately”. Journal of Second Language Writing 16/4 (2007) 255-272.

Ülper H. (2012). “Taslak Metinlere Öğretmenler Tarafindan Sunulan Geribildirimlerin Özellikleri”. Eğitim ve Bilim 37/165 (2012) 121-136.

Van Beuningen C. G., De Jong N. H. \& Kuiken F. (2008). "The Effect of Direct and Indirect Corrective Feedback on L2 Learners' Written Accuracy”. ITL International Journal of Applied Linguistics 156 (2008) 279-296.

Vyatkina N. (2010). “The Effectiveness of Written Corrective Feedback in Teaching Beginning German”. Foreign Language Annals 43 (2010) 671-689.

Wang T. \& Jiang L. (2015). "Studies on Written Corrective Feedback: Theoretical Perspectives, Empirical Evidence, and Future Directions”. English Language Teaching 8/1 (2015) 110-120.

Widdowson H. (1983). "New Starts and Different Kinds of Failure”. Eds. A. Freedman, I. Pringle \& J. Yalden. Learning to Write: First Language/Second Language (1983) 31-47. London.

Yeh S. W. \& Lo J. J. (2009). "Using Online Annotations to Support Error Correction and Corrective Feedback”. Computers and Education: An International Journal 52/2 (2009) 882-892. 